\title{
Numerical Evaluation of Francis Turbine Test Rig at Different Loads
}

\author{
Satyam Murari* and Sudarshan Prasad \\ College of Agricultural Engineering, Dr. Rajendra Prasad Central Agricultural University, \\ Pusa (Bihar), India \\ *Corresponding author
}

\begin{abstract}
A B S T R A C T
\section{Keywords}

Francis turbine test rig, energy, unit discharge, unit speed, unit power, efficiency

Article Info

Accepted:

11 June 2020

Available Online:

10 July 2020

The lab experiment was carried out to study the performance and characteristics of a Francis turbine test rig, in the Hydraulics Lab of the College Agricultural Engineering under Dr. Rajendra Prasad Central Agricultural University, Pusa (Bihar) India. The performance of the rig was evaluated at various loads ranging from 0 to $7.0 \mathrm{~kg}$ at a constant head of $7.68 \mathrm{~m}, 0$ to $5.0 \mathrm{~kg}$ at a constant head of $9.09 \mathrm{~m}$ and 0 to $4.0 \mathrm{~kg}$ at a constant head of $10.22 \mathrm{~m}$ of water, respectively. Results showed that as the loads applied increases, the water flow rate and input power to the rig increases, reaches up to the peak and then decreases at constant heads. Inverse relationship was observed between the torque developed due to the loads applied and the speed of the runner of the turbine operating at a constant head. The excellent correlation between the torque generated and the speed were found to be 99.87 $\%$ at constant heads of $7.68 \mathrm{~m}$ and $9.09 \mathrm{~m}$; and $99.80 \%$ at constant head of $10.22 \mathrm{~m}$ of water. As the load applied increases, the torque developed increases but at the same time speed of the runner of the turbine decreases. The output power developed by the rig increases with increase in load applied and reaches up to the peak values of $0.212 \mathrm{HP}$ at load of $4.0 \mathrm{~kg}, 0.534 \mathrm{HP}$ at load of $5.0 \mathrm{~kg}$ and $0.277 \mathrm{HP}$ at load of $3.0 \mathrm{~kg}$ at constant heads of $7.68 \mathrm{~m}, 9.09 \mathrm{~m}$ and $10.22 \mathrm{~m}$ of water, respectively and then decreases. The efficiency of the rig increases and reaches up to the maximum values of $32.23 \%$, $39.09 \%$ and $37.56 \%$ at the same value of load of $4.0 \mathrm{~kg}$ and at constant heads of $7.68 \mathrm{~m}, 9.09 \mathrm{~m}$ and $10.22 \mathrm{~m}$ of water, respectively and then decreases.
\end{abstract}

\section{Introduction}

Due to increasing human population, use of water for various purposes such as domestic, industrial development, hydropower generation, agriculture and environmental services has increased considerably over time. Water use for irrigation for instance, accounts for about 70 to $80 \%$ of the total freshwater available worldwide and irrigation has been ranked as one of the activities that utilize huge amounts of fresh water in many countries and in the near future, less water will be available for agricultural production due to competition with other sectors. At the same time, food production will have to be increased to feed the growing world population estimated at 81 million persons per year (UN, 2013) or about 9 billion people by 2050.

In order to provide adequate amount of water to meet out the demand of water requirement of all crops, adequate design of a water pumping plant operated either by engine or electric motor is required for which constant 
and high voltage of electric energy is required. The hydraulic turbine contributes the main function in supplying the electric energy to the agricultural pumping set and water pumping plant for domestic water supply in urban and rural areas as well as agricultural sector.

Hydroelectric energy is a domestic source of energy, allowing each state to produce their own energy without being reliant to others. The energy generation can be seen as essential to India's ability to raise living standards across the country, with 400 million citizens currently living without access to it (Mishra et al., 2015). National demand was predicted to grow from 250,000 MW in 2015 to $800,000 \mathrm{MW}$ in 2031-32 (Mishra et al., 2015). Francis turbines are the most preferred hydraulic turbines which is used to generate electricity using flowing water in River to meet out the human requirements for the survival and making the life comfortable. It is an inward-flow reaction turbine that combines radial and axial flow concepts. Francis turbines are the most common water turbine in use today. The aim for turbine design is to increase the efficiency and avoid cavitation. The main components of the turbines are spiral case, stay vanes, guide vanes, turbine runner and the draft tube whose dimensions are dependent mainly on the design discharge, head and the speed of the rotor of the generators. The design process starts with the selection of initial dimensions, iterates to improve the overall hydraulic efficiency and obtain the detailed description of the final geometry for manufacturing with complete visualization of the computed flow field. Water enters into the turbine through the outer periphery of the runner in the radial direction and leaves the runner in the axial direction, and hence it is also known as mixed flow turbine. Turbines are subdivided into impulse and reaction machines. In the impulse turbines, the total head available i.e. hydroenergy is converted into the kinetic energy. In the reaction turbines, only some part of the available total head of the fluid is converted into kinetic energy so that the fluid entering into the runner has pressure energy as well as kinetic energy. The pressure energy is then converted into kinetic energy in the runner and further converted into mechanical energy that was used as prime mover for a generator attached axially with the turbine. James B. Francis, in the year of 1848 while working as head engineer of the Locks and Canals Company in the water-powered factory city of Lowell, Massachusetts, improved the designs to create a turbine with $90 \%$ efficiency. He applied scientific principles and testing methods to produce a very efficient turbine design. More importantly, his mathematical and graphical calculation methods improved turbine design and engineering.

Christophe et al., (2004) stated that the phase shift analysis of the measured pressure fluctuations in the draft tube at this frequency points out a pressure source located in the inner part of the draft tube elbow. They showed that there is energy uniformly distributed in the range 0 to $7 \mathrm{fn}$ during spectral analysis of the pressure signal at the location. They calculated the wave speed along the draft tube using the experimental results of the phase shifts and allows modeling the entire test rig with SIMSEN. They provided the Eigen frequencies of the full hydraulic system during the simulation of the hydro acoustic behavior of the entire test rig, including the scale model and the piping system, and considering white noise excitation at the pressure source location. They identified an Eigen frequency at $2.46 \mathrm{fn}$ and the corresponding mode shape agrees well with the experimental results. They concluded that this excitation represents the synchronous part of the vortex rope excitation and the energy provided by the impacts on the 
draft tube wall. They showed the significant pressure amplitude mainly at $2.46 \mathrm{fn}$, which evidences the excitation mechanism during the analysis of the resulting pressure fluctuation in the entire test rig shows.

Lewis et al., (2014) mentioned that the process of arriving at the design of the modern Francis runner lasted from 1848 to approximately 1920 . They further advocated that though the modern Francis runner has little resemblance to the original turbines designed by James B. Francis in 1848, it became known as the Francis turbine around 1920 , in honor of his many contributions to hydraulic engineering analysis and design. They stated that the modern Francis turbine is the most widely used turbine design today, particularly for medium head and large flow rate situations, and can achieve over 95\% efficiency.

Aakti et al., (2015) performed the fully 360 degrees transient and steady-state simulations of a Francis turbine at three operating conditions, namely at part load (PL), best efficiency point (BEP), and high load (HL), using different numerical approaches for the pressure-velocity coupling. They simulated the spiral casing with stay and guide vanes, the runner and the draft tube. They included the numerical prediction of the overall performance of the high head Francis turbine model as well as local and integral quantities of the complete machine in different operating conditions. They compared the results with experimental data published by the workshop organization. They showed that the overall performance is well captured by the simulations. They concluded that the axial velocity is better estimated than the circumferential component at the local flow distributions within the inlet section of the draft-tube. Foroutan and Yavuzkurt (2015) studied the flow in the draft tube of a Francis turbine operating under various conditions using computational fluid dynamics (CFD). They considered the four operating points with the same head and different flow rates corresponding to $70 \%, 91 \%, 99 \%$, and $110 \%$ of the flow rate at the best efficiency point. They performed the unsteady numerical simulations using a recently developed partially averaged Navier-Stokes (PANS) turbulence model. They compared the results obtained during experiment with the numerical results of the traditionally used Reynolds-Averaged Navier-Stokes (RANS) models. They investigated the several parameters including the pressure recovery coefficient, mean velocity, and time-averaged and fluctuating wall pressure. They showed that RANS and PANS both can predict the flow behaviour close to the BEP operating condition.

They concluded that the RANS results deviate considerably from the experimental data as the operating condition moves away from the BEP. They found that the pressure recovery factor predicted by the RANS model shows more than $13 \%$ and $58 \%$ over prediction when the flow rate decreases to $91 \%$ and $70 \%$ of the flow rate at BEP, respectively. They stated that the predictions can be improved significantly using the present unsteady PANS simulations. They predicted the pressure recovery factor by less than $4 \%$ and $6 \%$ deviation for these two operating conditions.

Guo, et al., (2017) analysed the formation and inevitability of diversified hydraulic phenomena on model efficiency hill chart for typical head range. They discussed and summarized characteristics and commonness toward the curves by comparing. Furthermore, they presented the hydraulic performance and geometric features by analysing the efficiency hill charts. They summarised that the inherent characteristics of Francis turbine is expressed by all kinds of 
curves on the model efficiency hill charts, and these curves can be adjusted and moved in a small range but cannot be removed out. They observed the incipient cavitation curve on suction side due to wide range of unit speed in terms of medium-low-head hydraulic turbines and they recommended to position close to the operation zone. They concluded that the blade channel vortex curves are in the vicinity of optimum region for low-head hydraulic turbines, while high-head shows reverse trend. They inferred that the interaction between zero incidence angle and zero circulation curve has a significant influence on iso-efficiency circles.

Shanab et al., (2017) carried out the performance test on the test rig of a Francis turbine for various gate opening of the turbine in the Fluid Mechanics laboratory at Mechanical Engineering Department manufactured by Gilbert Gilkes and Gordon Ltd, representing a Francis turbine hydro power plant model. They concentrated their study with focus on the characteristics of the Francis turbine model. They numerical implemented the results for the test rig to get dedicated values of the six partial coefficients of the Francis Turbine test rig that used for control studies. They compared the partial coefficients with ideal model values. They upgraded the manual test rig to control the measurements automatically. They developed the variables measurement technology of the turbine and implemented by using Lab VIEW software interface.

Teressa et al., (2018) conducted test on Francis turbine to know their dead-on behaviour under varying conditions in Fluid Mechanics and Hydraulics Machines Laboratory, Koneru Lakshmaih Education Foundation, India. They plotted the results obtained graphically and developed the constant head or constant speed characteristics curve. They focused mainly on the experimental analysis to get actual performance characteristics curves. They carried out the entire experiment in the Laboratory maintaining the constant head and gate opening. They measured the BHP automatically by eddy dynamometer. They plotted the curves between unit discharge and unit speed for Francis turbine. They found the rising curves between unit discharge and unit speed. They observed the increasing discharge with the increase in speed. Finally, they calculated overall efficiency of turbine along with percentage of full load.

Abas and Kumar (2019) performed the in-situ calibration of different measuring instruments viz. flow meter, measuring tank load cells, calibrator tank load cell, shaft torque transducer, friction torque load cell and speed transducer used in turbine model testing and derived the calibration equations from their calibration curves. They adopted the gravimetric approach using the flying start and stop method for flow calibration in present study.

They evaluated the Type A and Type B uncertainties of weighing balance and flow diverter has been evaluated and conducted the performance test on the model and efficiency as well as others flow parameters viz. discharge, head, speed and torque have been obtained at 16 different operating points including finding out Type A uncertainty in efficiency measurement. They calculated the regression error for Type A and Type B uncertainties at each operating point in order to find out total uncertainty of flow and performance parameters. They found out minimum of total uncertainty in flow measurement and efficiency measurement at the best efficiency point when compared with other operating points. They developed a correlation for the estimation of uncertainty in the efficiency measurement with an error of $\pm 9 \%$. 


\section{Materials and Methods}

\section{Experimental site and setup}

The experiment was conducted in the Hydraulic Lab of the College of Agricultural Engineering, Dr. Rajendra Prasad Central Agricultural University, Pusa. The place, Pusa is situated on the bank of the river BurhiGandak in the Samastipur district of North Bihar, India. It has a latitude of $25^{\circ} 29^{\prime}$ North, a longitude of $83^{\circ} 48^{\prime}$ East and situated at an altitude of 53.0 meter above mean sea level. Pusa is endowed with fair climate having average annual rainfall of around 1200 $\mathrm{mm}$.

The set up consists a centrifugal pump in built with the rig, a venturimeter attached in concentric with the discharge pipe, turbine unit and sump tank arranged in such a way that the whole unit works as re-circulating water system. The centrifugal pump supplies water from the sump to the turbine through the venturimeter unit.

The load of the turbine was achieved by rope brake drum connected with weight balance. The flow of water through the pipe line that creates pressure for the turbine, was measured with the help of the venturimeter unit (Fig. 1).

\section{Components of the francis turbine test rig prime mover}

A centrifugal pump attached with a 5 HP electric motor as prime mover, supplies water for the turbine at a rated pressure head of 18.0 $\mathrm{m}$ and at a speed of $2870 \mathrm{RPM}$.

\section{Venturimeter}

A venturimeter of size $40 \mathrm{~mm}$ is fitted concentric with the discharge pipe of $80 \mathrm{~mm}$ size that carries water to the turbine, was used to measure the water flow rate. The pressure drop across the venturimeter was measured with the help of a U-tube differential manometer, attached with the rig.

\section{Butterfly valve}

A Butterfly valve fitted in pipeline of the rig was used to stop, regulate, and start the flow in the pipeline. The valve has a disc which is mounted on a rotating shaft. When the butterfly valve is fully closed, the disk completely blocks the line and vice-versa.

\section{Pressure gauge and vacuum gauge}

Mechanical pressure gauge and vacuum gauge fitted at inlet and outlet side of the turbine, respectively were used to measure the pressure head of water flow. Both the mechanical and vacuum gauges are capable to record the pressure up to $4.0 \mathrm{Kg} / \mathrm{cm}^{2}$ and 1.03 $\mathrm{Kg} / \mathrm{cm}^{2}$ (760 mm of $\mathrm{Hg}$ ), respectively.

\section{Break drum}

A break drum of $200 \mathrm{~mm}$ size mounted on the runner's shaft of the turbine was used to develop torque on the turbine. A spring balance, a type of weighing scale connected with one end of a $10 \mathrm{~mm}$ round size of a rope was used to measure the load applied on the runner. A hanger of $0.5 \mathrm{Kg}$ connected with the other end of the rope was used to measure the load applied on the runner.

\section{Spiral casing}

The water enters from the penstock (pipeline leading to the turbine from the reservoir at high altitude) to a spiral casing called volute which completely surrounds the runner of the turbine fitted horizontally. The cross-sectional area of this casing decreases uniformly along the circumference to keep the fluid velocity constant in magnitude along its path towards the stay vane. 
This is so because the rate of flow along the fluid path in the volute decreases due to continuous entry of the fluid to the runner through the openings of the stay vanes.

\section{Stay vanes}

Water flow is directed toward the runner by the stay vanes as it moves along the spiral casing, and then it passes through the wicket gates where a part of pressure energy is converted into kinetic energy. The wicket gates impart a tangential velocity and hence an angular momentum to the water before its entry to the runner.

\section{Runner}

It is the main part of the turbine that has blades on its periphery. During operation, runner rotates and produces power. The flow is inward, i.e. from the periphery towards the centre. The main direction of flow changes as water passes through the runner and is finally turned into the axial direction while entering the draft tube.

\section{Draft tube}

The draft tube is a conduit which connects the runner exit to the tail race where the water is finally discharged to the sump tank from the turbine. The primary function of the draft tube is to reduce the velocity of the discharged water to minimize the loss of kinetic energy at the outlet. After passing through the runner, the flow of water at high speed enters an expanding area (diffuser) called draft tube, which slows down the flow speed, while increasing the pressure prior to discharge into the downstream water.

\section{Determination of water flow rate}

The flow rate of water, $\mathrm{Q}\left(\mathrm{m}^{3} / \mathrm{sec}\right)$ through the pipe line into the turbine was determined with the help of venturimeter by using following equation :

$\mathrm{Q}=C_{d} \frac{a_{1} a_{2} \sqrt{2 g h}}{\sqrt{a_{1}^{2}-a_{2}^{2}}}$

Where, $C_{d}$ is the co-efficient of discharge $(0.96$ for venturimeter), $a_{1}$ is the cross sectional area of pipeline $\left(\mathrm{m}^{2}\right), a_{2}$ is the cross sectional area of throat of the venturimeter $\left(\mathrm{m}^{2}\right), \mathrm{g}$ is the acceleration due to $\operatorname{gravity}\left(9.8 \mathrm{~m} / \mathrm{sec}^{2}\right)$ and $h$ is the pressure difference between the throat of the venturimeter and the pipe line which was computed as follows :

$h=y\left(\frac{S_{H g}}{S_{W}}-1\right)$

Where, $\mathrm{h}$ is the pressure drop across the venturimeter (m of water), y is equal to $h_{1}-$ $h_{2}$ (m of mercury), $\mathrm{S}_{\mathrm{Hg}}$ is the specific gravity of mercury and $S_{W}$ is the specific gravity of water.

\section{Determination of total head}

The available total head, $\mathrm{H}$ (m of water) for the turbine was determined after the losses in pressure when water flow through the waterways using the following equation :

$H=\left(P+\frac{V}{760}\right) \times 10$

Where, $\mathrm{P}$ is the turbine inlet gauge pressure $\left(\mathrm{kg} / \mathrm{cm}^{2}\right)$ and $\mathrm{V} \quad$ is the turbine vacuum gauge pressure $\left(\mathrm{kg} / \mathrm{cm}^{2}\right)$

\section{Computation of input power}

The input power supplied at the inlet of turbine was determined by using the equation mentioned as under:

$P_{I}=\frac{\rho * g * Q * H}{746}$ 
Where, $\mathrm{P}_{\mathrm{I}}$ is the input power available to run the turbine (HP), $\mathrm{H}$ is the total head(m)and $\rho$ is the density of water $\left(1000 \mathrm{~kg} / \mathrm{m}^{3}\right.$ at normal temperature).

\section{Calculation of torque}

The torque applied on the runner of the turbine through the break drum was determined with the help of the equation given below :

$$
\begin{aligned}
& \mathrm{T}=\left(\mathrm{T}_{0}+\mathrm{T}_{1}-\mathrm{T}_{2}\right) \times \mathrm{D} \\
& D=\frac{\left(d_{1}+2 \times d_{2}\right)}{2}
\end{aligned}
$$

Where, $\mathrm{T}$ is the torque applied on the turbine $(\mathrm{N} \mathrm{m}), \mathrm{T}_{0}$ is the weight of hanger $(\mathrm{Kg}), \mathrm{T}_{1}$ is the weight applied on hanger $(\mathrm{Kg}), \mathrm{T}_{2}$ is the spring load $(\mathrm{Kg}), \mathrm{d}_{1}$ is the diameter of break drum $(m), d_{2}$ is the diameter of rope $(m)$ and $\mathrm{D}$ is the equivalent diameter $(\mathrm{m})$.

\section{Determination of output power}

The output power, $\mathrm{P}_{\mathrm{o}}$ (HP) developed by the turbine was computed using the equation mentioned below :

$P_{O}=\frac{\pi * \mathrm{~N} * \mathrm{~T}}{4500}$

Where, $\mathrm{N}$ is the revolution of the turbine per minute (RPM) which was measured by using the digital tachometer operated with 9 volt DC battery.

\section{Computation of efficiency}

The ability of the hydraulic turbine to transmit the potential energy by rotation is known as the efficiency of the turbine, $\eta$ (per cent) which was computed as:

$$
\mathrm{\eta}=\frac{\mathrm{p}_{0}}{\mathrm{p}_{I}} \times 100
$$

\section{Computation of unit discharge, unit speed} and unit power

If a turbine is working under different heads, the behaviour of the turbine can be characterised easily from the unit quantities such as unit discharge $\left(Q_{U}\right)$, unit speed $\left(N_{U}\right)$ and unit power $\left(P_{U}\right)$ of the turbine which provide the speed, discharge and power for a Francis turbine under a pressure head of 1 meter assuming the same efficiency. These unit quantities can be expressed as follows :

$Q_{U}=\frac{Q}{\sqrt{H}}$

$P_{U}=\frac{P}{H^{\mathrm{g} / 2}}$

$N_{U}=\frac{N}{\sqrt{H}}$

\section{Results and Discussion}

\section{Computation of discharge and input power developed at different loads and heads}

The Francis turbine was operated at constant heads of $7.68 \mathrm{~m}, 9.09 \mathrm{~m}$ and $10.22 \mathrm{~m}$ of water and at applied loads ranging from 0 to $7.0 \mathrm{~kg}$, 0 to $5.0 \mathrm{~kg}$ and 0 to $4.0 \mathrm{~kg}$, respectively. The constant heads at particular loads applied to develop the torque on the runner of the turbine were maintained through the gate valve during the operation of the turbine. The pressure drop across the venturimeter was recorded with the help of U-tube manometer. Thus, the water flow rate through the pipe line and the input power developed by the turbine at various loads and constant head of $7.68 \mathrm{~m}$ of water were computed with the help of Eq. Nos. (1) and (4), respectively and presented in Table 1 which clearly shows that at no load and maximum applied load of $7.0 \mathrm{~kg}$, the 
water flow rate of $4.80 \times 10^{-3} \mathrm{~m}^{3} / \mathrm{sec}$ and $5.185 \times 10^{-3} \mathrm{~m}^{3} / \mathrm{sec}$, respectively were observed while the highest water flow rate of $6.500 \times 10^{-3} \mathrm{~m}^{3} / \mathrm{sec}$ at applied load of $3.0 \mathrm{~kg}$ and $4.0 \mathrm{~kg}$ was found at constant head of 7.68 $\mathrm{m}$ of water. On the other hand, the input power of $0.524 \mathrm{HP}$ at no load and that of $0.485 \mathrm{HP}$ at maximum applied load of $7.0 \mathrm{~kg}$ were noticed whereas the maximum input power of $0.656 \mathrm{HP}$ at applied loads of $3.0 \mathrm{~kg}$ and $4.0 \mathrm{~kg}$ were found during the operation of the turbine at constant head of $7.68 \mathrm{~m}$ of water. Table 1 also reveals that the pressure drop across the venturimeter fitted in concentric with the pipe line was recorded as $0.756 \mathrm{~m}$ of water at no load and $0.882 \mathrm{~m}$ of water at maximum load of $7.0 \mathrm{~kg}$ whereas it was observed to be maximum of $1.386 \mathrm{~m}$ of water at loads of $3.0 \mathrm{~kg}$ and $4.0 \mathrm{~kg}$ at constant head of $7.68 \mathrm{~m}$ of water.

Similarly, the water flow rate and the input power developed by the turbine at various loads ranging from 0 to $5.0 \mathrm{~kg}$ at constant head of $9.09 \mathrm{~m}$ and from 0 to $4.0 \mathrm{~kg}$ at constant head of $10.22 \mathrm{~m}$ of water were computed and presented in tables 2 and 3, respectively. Table 2 depicts that the minimum discharge of $4.80 \times 10^{-3} \mathrm{~m}^{3} / \mathrm{sec}$ and that of $6.040 \times 10^{-3} \mathrm{~m}^{3} / \mathrm{sec}$ were observed at no load and maximum load of $5.0 \mathrm{~kg}$, respectively however, the maximum discharge of $6.646 \times 10^{-3} \mathrm{~m}^{3} / \mathrm{sec}$ was found at applied load of $3.0 \mathrm{~kg}$ and at constant head of $9.09 \mathrm{~m}$ of water.

Table 2 also shows the input power of 0.574 $\mathrm{HP}$ and $0.722 \mathrm{HP}$ at no load and at maximum applied load of $5.0 \mathrm{~kg}$, respectively while the maximum input power of $0.794 \mathrm{HP}$ was obtained at applied load of $3.0 \mathrm{~kg}$ during the operation of the turbine at a constant head of $9.09 \mathrm{~m}$ of water. The pressure drop of 0.756 $\mathrm{m}$ and $1.197 \mathrm{~m}$ of water at no load and at maximum load of $5.0 \mathrm{~kg}$, respectively were depicted whereas it was maximum of $1.386 \mathrm{~m}$ of water at load of $4.0 \mathrm{~kg}$ at constant head of $9.09 \mathrm{~m}$ of water. Similar trend of water flow rate through the pipe line of the turbine, pressure drop across the venturimeter and input power of the turbine were observed at constant head of $10.22 \mathrm{~m}$ of water.

The pressure drop was found to be $0.756 \mathrm{~m}$ and $0.907 \mathrm{~m}$ of water at no load and at maximum load of $4.0 \mathrm{~kg}$, respectively whereas the maximum pressure drop of 1.134 $\mathrm{m}$ of water at applied load of $3.0 \mathrm{~kg}$ was observed at constant head of $10.22 \mathrm{~m}$ of water. Moreover, at no load and maximum applied load of $4.0 \mathrm{~kg}$, the water flow rate of $4.80 \times 10^{-3} \mathrm{~m}^{3} / \mathrm{sec}$ and $5.259 \times 10^{-3} \mathrm{~m}^{3} / \mathrm{sec}$, and the input power of $0.645 \mathrm{HP}$ and 0.707 $\mathrm{HP}$, respectively were observed however, at applied load of $3.0 \mathrm{~kg}$ the maximum discharge of $5.879 \times 10^{-3} \mathrm{~m}^{3} / \mathrm{sec}$ and the maximum input power of $0.790 \mathrm{HP}$ were observed at constant head of $10.22 \mathrm{~m}$ of water (Table 3).

The water flow rate through the pipe line of the turbine at different loads applied and at constant heads of $7.68 \mathrm{~m}, 9.09 \mathrm{~m}$ and $10.22 \mathrm{~m}$ of water were graphically presented in Fig. 2. Fig. 2 distinctly shows the variation in water flow rate with the loads applied at constant heads of $7.68 \mathrm{~m}, 9.09 \mathrm{~m}$ and $10.22 \mathrm{~m}$ of water. Peak value of water flow rate was observed between $3.0 \mathrm{~kg}$ and $4.0 \mathrm{~kg}$ of loads applied while minimum value of water flow rate was found at both the end i.e. at no load and at maximum load of $7.0 \mathrm{~kg}$ at constant head of m7.68 m of water. Similar trend in water flow rate at applied loads from 0 to 5.0 $\mathrm{kg}$ at constant head of $9.09 \mathrm{~m}$ and that from 0 to $4.0 \mathrm{~kg}$ at constant head of $10.22 \mathrm{~m}$ of water was observed (Fig. 2).

Tables 1, 2 and 3 and Fig. 2 infer that the minimum water flow rate of $4.80 \times 10^{-3}$ $\mathrm{m}^{3} / \mathrm{sec}$ through the pipe line of the turbine were found at no load operating under 
constant head of $7.68 \mathrm{~m}$ of water. However, peak discharge of $6.500 \times 10^{-3} \mathrm{~m}^{3} / \mathrm{sec}$ at constant head of $7.68 \mathrm{~m}, 6.646 \times 10^{-3} \mathrm{~m}^{3} / \mathrm{sec}$ at constant head of $9.09 \mathrm{~m}$ and $5.879 \times 10^{-3}$ $\mathrm{m}^{3} / \mathrm{sec}$ at constant head of $10.22 \mathrm{~m}$ of water operating under same applied load of $3.0 \mathrm{~kg}$ were achieved. Tables and figure depicted the highest input power of $0.656 \mathrm{HP}, 0.794 \mathrm{HP}$ and $0.790 \mathrm{HP}$ of the turbine operating at the same applied load of $3.0 \mathrm{~kg}$ at constant heads of $7.68 \mathrm{~m}, 9.09 \mathrm{~m}$ and $10.22 \mathrm{~m}$ of water, respectively. It was observed that as the loads applied increases, the water flow rate and input power of the turbine increases and reaches up to the peak and then decreases at constant head of the turbine.

\section{Determination of turbine characteristics at different loads and constant heads}

The loads were applied to develop the torque on the runner of the turbine during its operation. The torques, output power and efficiency of the turbine at various loads applied ranging from 0 to $7.0 \mathrm{~kg}$ at constant head of $7.68 \mathrm{~m}, 0$ to $5.0 \mathrm{~kg}$ at constant head of $9.09 \mathrm{~m}$ and 0 to $4.0 \mathrm{~kg}$ at constant head of $10.22 \mathrm{~m}$ of water were determined with the help of Eq. Nos. (5), (7) and (8), and presented in Tables 4, 5 and 6, respectively. Table 4 distinctly shows the minimum torque of $0.033 \mathrm{~kg}-\mathrm{m}$ and maximum of $0.66 \mathrm{~kg}-\mathrm{m}$ at no load and at maximum applied load of 7.0 $\mathrm{kg}$, respectively. The speed of the runner of the turbine was found to be maximum (1222 RPM) and minimum (30 RPM) at no load and at maximum applied load of $7.0 \mathrm{~kg}$, respectively. The minimum output power of $0.028 \mathrm{HP}$ followed by $0.082 \mathrm{HP}$ were developed by the turbine at no load and at applied load of $6.0 \mathrm{~kg}$, respectively while maximum power of $0.212 \mathrm{HP}$ was found at applied load of $4.0 \mathrm{~kg}$. As far as the efficiency of the turbine is concerned, it was minimum of $2.64 \%$ at applied load of $7.0 \mathrm{~kg}$ followed by $5.82 \%$ at no load applied whereas it was maximum of $32.23 \%$ at applied load of 4.0 $\mathrm{kg}$ on the runner of the turbine at constant head of $7.68 \mathrm{~m}$ of water (Table 4 ).

Similarly, the minimum and maximum torque of $0.033 \mathrm{~kg}-\mathrm{m}$ and $0.534 \mathrm{~kg}-\mathrm{m}$ were observed at no load and at maximum applied load of $5.0 \mathrm{~kg}$ whereas maximum speed of $1400 \mathrm{RPM}$ at no load and minimum speed (620 RPM) of the runner of the turbine at maximum load of $5.0 \mathrm{~kg}$ were recorded. The output power developed by the turbine was found to be minimum of $0.033 \mathrm{HP}$ at no load and maximum of $0.534 \mathrm{HP}$ at maximum applied load of $5.0 \mathrm{~kg}$ at constant head of $9.09 \mathrm{~m}$ of water. As far as the efficiency of the turbine is concerned, the maximum efficiency was observed to be $39.09 \%$ at applied load of 4.0 $\mathrm{kg}$ whereas that of minimum was found to be $5.18 \%$ at no load and at constant head of 9.09 $\mathrm{m}$ of water (Table 5).

Table 6 shows that the minimum and maximum torque developed were found to be $0.033 \mathrm{~kg}-\mathrm{m}$ at no load and $0.451 \mathrm{~kg}-\mathrm{m}$ at maximum applied load of $4.0 \mathrm{~kg}$ whereas the maximum and minimum speed of the runner of the turbine were observed to be 1750 RPM at no load and 900 RPM at maximum applied load of $4.0 \mathrm{~kg}$ and at constant head of $10.22 \mathrm{~m}$ of water. However, the minimum and maximum output power developed by the turbine and its efficiency were computed as $0.042 \mathrm{HP}$ and $6.56 \%$ at no load and $0.266 \mathrm{HP}$ and $37.56 \%$ at full load of $4.0 \mathrm{~kg}$ and at constant head of $10.22 \mathrm{~m}$ of water (Table 6).

The torque developed on the runner of the turbine and it speed were graphically presented in Fig, 3 to show the relationship between torque and speed of the runner of the turbine. Fig. 3 distinctly shows the inverse relationship i.e. negative trend between the torque and speed of the runner at constant head of $7.07 \mathrm{~m}, 9.09 \mathrm{~m}$ and $10.22 \mathrm{~m}$ of water. The excellent correlation between torque 
generated by the loads applied on the runner of the turbine and its speed were found to be $99.87 \%$ at constant head of $7.68 \mathrm{~m}$ and 9.09 $\mathrm{m}$ of water and $99.80 \%$ at constant head of $10.22 \mathrm{~m}$ of water.

Table 4, 5, 6 and Fig. 3 distinctly revealed the inverse relationship between the torque developed due to the application of loads and the speed of the runner of the turbine operating at constant head. The excellent correlation between torque generated and speed were found to be $99.87 \%$ at constant head of $7.68 \mathrm{~m}$ and $9.09 \mathrm{~m}$ of water and 99.80 $\%$ at constant head of $10.22 \mathrm{~m}$ of water. It was observed that as the load applied increases the torque developed increases but at the same time speed of the runner of the turbine decreases. Tables show that as the application of loads increases, the output power developed by the turbine increases and reaches up to the peak values of $0.212 \mathrm{HP}$ at load $4.0 \mathrm{~kg}, 0.534 \mathrm{HP}$ at load $5.0 \mathrm{~kg}$ and $0.277 \mathrm{HP}$ at load $3.0 \mathrm{~kg}$ at constant heads of $7.68 \mathrm{~m}, 9.09 \mathrm{~m}$ and $10.22 \mathrm{~m}$ of water, respectively and then decreases. Similarly, as loads applied increases, the efficiency of the turbine increases and reaches up to the maximum values of $32.23 \%, 39.09 \%$ and 37.56 at the same value of load $4.0 \mathrm{~kg}$ and at constant heads of $7.68 \mathrm{~m}, 9.09 \mathrm{~m}$ and $10.22 \mathrm{~m}$ of water, respectively and then decreases.

\section{Unit quantities and characteristics of the francis turbine}

The unit quantities such as unit discharge, unit power and unit speed were calculated with the help of eqs. (9), (10) and (11), respectively to study the behaviour of the turbine working under different heads and presented in Table 7 which clearly indicates that the minimum unit discharge of $1.732 \times$ $10^{-3}$ followed by $1.871 \times 10^{-3} \mathrm{~m}^{3} / \mathrm{sec}$ per meter head of water at no load and at maximum load were detected while the maximum and the minimum unit speed of the runner of 441 RPM and 11 RPM per meter head of water were observed at no load and full load, respectively.

However, the maximum unit discharge of $2.345 \times 10^{-3} \mathrm{~m}^{3} / \mathrm{sec}$ per meter head of water was found at applied load of $4.0 \mathrm{~kg}$ at constant head of $7.68 \mathrm{~m}$ of water. The minimum unit power of 0.132 HP per $m$ head at no load was found while the maximum unit power of $0.996 \mathrm{HP}$ per $\mathrm{m}$ head of water at a load of $4.0 \mathrm{~kg}$ was observed at constant head of $7.68 \mathrm{~m}$ of water (Table 7). Similarly, the minimum values of unit discharge of $1.592 \times$ $10^{-3}$ and $1.501 \times 10^{-3} \mathrm{~m}^{3} / \mathrm{sec}$ per meter head at no load and at constant head of $9.09 \mathrm{~m}$ and $10.22 \mathrm{~m}$ of water, respectively were observed whereas the maximum values of unit discharge of $2.204 \times 10^{-3}$ and $1.839 \times 10^{-3}$ $\mathrm{m}^{3} / \mathrm{sec}$ per meter head at a load of $3.0 \mathrm{~kg}$ and at constant head of $9.09 \mathrm{~m}$ and $10.22 \mathrm{~m}$ of water, respectively were detected. However, the minimum input power of $0.120 \mathrm{HP}$ and $0.153 \mathrm{HP}$ per $\mathrm{m}$ head of water at no load were obtained while the maximum power of 1.948 $\mathrm{HP}$ at full load and 1.011 $\mathrm{HP}$ per $\mathrm{m}$ head at load of $3.0 \mathrm{~kg}$ were observed at constant head of $9.09 \mathrm{~m}$ and $10.22 \mathrm{~m}$ of water, respectively (Table.7).

The scatter plots between the unit discharge and the unit speed at constant heads of 7.68 $\mathrm{m}, 9.09 \mathrm{~m}$, and $10.22 \mathrm{~m}$ of water were plotted and shown in Fig. 4.

The Fig 4 depicts that the unit discharge increases and reaches up to a peak then decreases with increasing values of unit speed at constant head of $7.68 \mathrm{~m}$ of water. Similar trend following the parabolic line was observed at constant head of $9.09 \mathrm{~m}$ and 10.22 of water. The scatter plot between the unit power and unit speed and the efficiency and unit speed of the turbine operating at constant heads of $7.68 \mathrm{~m}, 9.09 \mathrm{~m}$, and 10.22 
$m$ of water were plotted and shown in Figs. 5 and 6 , respectively. The Fig 5 shows the increasing trend of unit power with increasing values of unit speed at constant heads of 7.68 $\mathrm{m}, 9.09 \mathrm{~m}$, and $10.22 \mathrm{~m}$ of water. After reaching up to maximum unit power of 0.010 $\mathrm{HP}$ and $0.011 \mathrm{HP}$ at unit speed of $279 \mathrm{RPM}$ and $231 \mathrm{RPM}$ at constant head of $7.68 \mathrm{~m}$ and $9.09 \mathrm{~m}$ of water, respectively it start declining following a parabolic line.

Maximum unit power was obtained at constant head of $10.22 \mathrm{~m}$ while the minimum power was found at constant head of $9.09 \mathrm{~m}$ of water (Fig 5). Similarly, Fig. 6 showed the increasing trend of efficiency (\%) with increasing unit speed (RPM) but after reaching maximum efficiency it started decreasing with increasing unit speed following the similar pattern of parabolic line. The maximum efficiency obtained was 32.23 $\%$ at unit head of 231 RPM and at constant head of $9.09 \mathrm{~m}$ however it was maximum of $39.09 \%$ at unit speed of 279 RPM and at constant head of $9.09 \mathrm{~m}$ of water. Whereas, the maximum efficiency of $37.00 \%$ at unit speed of 281 RPM and at constant head of $10.22 \mathrm{~m}$ of water was observed (Fig. 6).

The characteristics curves of the test rig to study the behaviour and performance characteristics of the rig working at various loads under constant head of $7.68 \mathrm{~m}$ of water were prepared and presented in Fig. 7. The discharge and torque of the rig was plotted on primary ordinate and the efficiency and power developed at secondary ordinate while speed was taken on abscissa. The efficiency and the power of the rig increases with increase in speed and after reaching up to maximum it decreases with further increase in speed following a parabolic pattern. Although, the torque was found to be inversely related with speed of the turbine. It decreases with increase in speed of the turbine. Increasing trend in water flow rate through the pipe line of the rig was observed at constant head of $7.68 \mathrm{~m}$ of water.

Table.1 Computation of water flow rate and input power of the rig operating at different loads and constant head of $7.68 \mathrm{~m}$

\begin{tabular}{|c|c|c|c|c|c|}
\hline \multirow{2}{*}{$\begin{array}{c}\text { Load } \\
\text { applied } \\
\text { (Kg) }\end{array}$} & \multicolumn{2}{|c|}{$\begin{array}{l}\text { Level of water in } \\
\text { manometer (m) }\end{array}$} & \multirow[t]{2}{*}{$\begin{array}{c}\text { Pressure drop } \\
\text { (m of water) }\end{array}$} & \multirow[t]{2}{*}{$\begin{array}{c}\text { Discharge }\left(\times 10^{-3}\right) \\
\left(\mathrm{m}^{3} / \mathrm{sec}\right)\end{array}$} & \multirow{2}{*}{$\begin{array}{r}\text { Input } \\
\text { power } \\
\text { (HP) }\end{array}$} \\
\hline & Left limb & Right limb & & & \\
\hline 0.0 & 0.190 & 0.130 & 0.756 & 4.800 & 0.524 \\
\hline 1.0 & 0.187 & 0.120 & 0.844 & 5.073 & 0.524 \\
\hline 2.0 & 0.190 & 0.110 & 1.008 & 5.543 & 0.574 \\
\hline 3.0 & 0.200 & 0.090 & 1.386 & 6.500 & 0.656 \\
\hline 4.0 & 0.200 & 0.090 & 1.386 & 6.500 & 0.656 \\
\hline 5.0 & 0.187 & 0.103 & 1.058 & 5.680 & 0.560 \\
\hline 6.0 & 0.180 & 0.110 & 0.882 & 5.185 & 0.512 \\
\hline 7.0 & 0.180 & 0.110 & 0.882 & 5.185 & 0.485 \\
\hline
\end{tabular}


Table. 2 Computation of water flow rate and input power of the rig operating at different loads and constant head of $9.09 \mathrm{~m}$

\begin{tabular}{|c|c|c|c|c|c|}
\hline \multirow{2}{*}{$\begin{array}{c}\text { Load } \\
\text { applied } \\
(\mathbf{K g})\end{array}$} & \multicolumn{2}{|c|}{$\begin{array}{l}\text { Level of water in } \\
\text { manometer (m) }\end{array}$} & \multirow[t]{2}{*}{$\begin{array}{c}\text { Pressure drop } \\
\text { (m of water) }\end{array}$} & \multirow[t]{2}{*}{$\begin{array}{c}\text { Discharge }\left(\times 10^{-3}\right) \\
\left(\mathrm{m}^{3} / \mathrm{sec}\right)\end{array}$} & \multirow{2}{*}{$\begin{array}{c}\begin{array}{c}\text { Input } \\
\text { power }\end{array} \\
\text { (HP) }\end{array}$} \\
\hline & Left limb & Right limb & & & \\
\hline 0.0 & 0.190 & 0.130 & 0.756 & 4.800 & 0.574 \\
\hline 1.0 & 0.190 & 0.120 & 0.882 & 5.190 & 0.620 \\
\hline 2.0 & 0.190 & 0.110 & 1.008 & 5.543 & 0.662 \\
\hline 3.0 & 0.210 & 0.095 & 1.449 & 6.646 & 0.794 \\
\hline 4.0 & 0.210 & 0.100 & 1.386 & 6.500 & 0.777 \\
\hline 5.0 & 0.200 & 0.105 & 1.197 & 6.040 & 0.722 \\
\hline
\end{tabular}

Table.3 Computation of water flow rate and input power of the rig operating at different loads and constant head of $10.22 \mathrm{~m}$

\begin{tabular}{|c|c|c|c|c|c|}
\hline \multirow[t]{3}{*}{$\begin{array}{l}\text { Load applied } \\
\text { (Kg) }\end{array}$} & \multicolumn{2}{|c|}{$\begin{array}{c}\text { Level of water in } \\
\text { manometer (m) }\end{array}$} & \multirow[t]{3}{*}{$\begin{array}{c}\text { Pressure drop } \\
\text { (m of water) }\end{array}$} & \multirow[t]{3}{*}{$\begin{array}{c}\operatorname{Discharge}\left(\times 10^{-3}\right) \\
\left(\mathrm{m}^{3} / \mathrm{sec}\right)\end{array}$} & \multirow{3}{*}{$\begin{array}{r}\text { Input } \\
\text { power } \\
\text { (HP) }\end{array}$} \\
\hline & Left limb & Right limb & & & \\
\hline & & & & & \\
\hline 0.0 & 0.170 & 0.110 & 0.756 & 4.800 & 0.645 \\
\hline 1.0 & 0.180 & 0.116 & 0.806 & 4.958 & 0.667 \\
\hline 2.0 & 0.200 & 0.114 & 1.084 & 5.747 & 0.773 \\
\hline 3.0 & 0.200 & 0.110 & 1.134 & 5.879 & 0.790 \\
\hline 4.0 & 0.190 & 0.118 & 0.907 & 5.259 & 0.707 \\
\hline
\end{tabular}

Table.4 Computation of rig characteristics at different loads and constant head of $7.68 \mathrm{~m}$

\begin{tabular}{|c|c|c|c|c|c|}
\hline $\begin{array}{c}\text { Load applied } \\
(\mathbf{k g})\end{array}$ & $\begin{array}{c}\text { Spring load } \\
(\mathbf{k g})\end{array}$ & $\begin{array}{c}\text { Torque } \\
\mathbf{( k g - m )}\end{array}$ & $\begin{array}{c}\text { Speed } \\
(\mathbf{R P M})\end{array}$ & $\begin{array}{c}\text { Output power } \\
(\mathbf{H P})\end{array}$ & $\begin{array}{c}\text { Efficiency } \\
(\mathbf{\%})\end{array}$ \\
\hline $\mathbf{0 . 0 0 0}$ & 0.200 & 0.033 & 1222 & 0.028 & 5.82 \\
\hline $\mathbf{1 . 0 0 0}$ & 0.250 & 0.138 & 1065 & 0.102 & 19.96 \\
\hline $\mathbf{2 . 0 0 0}$ & 0.300 & 0.242 & 870 & 0.174 & 31.16 \\
\hline $\mathbf{3 . 0 0 0}$ & 0.350 & 0.347 & 740 & 0.206 & 31.34 \\
\hline $\mathbf{4 . 0 0 0}$ & 0.450 & 0.446 & 640 & 0.212 & 32.23 \\
\hline $\mathbf{5 . 0 0 0}$ & 1.400 & 0.451 & 450 & 0.183 & 31.96 \\
\hline $\mathbf{6 . 0 0 0}$ & 1.450 & 0.556 & 190 & 0.082 & 15.56 \\
\hline $\mathbf{7 . 0 0 0}$ & 1.500 & 0.660 & 30 & 0.138 & 2.64 \\
\hline
\end{tabular}


Table.5 Computation of rig characteristics at different loads and constant head of $9.09 \mathrm{~m}$

\begin{tabular}{|c|c|c|c|c|c|}
\hline $\begin{array}{c}\text { Load applied } \\
(\mathbf{k g})\end{array}$ & $\begin{array}{c}\text { Spring load } \\
(\mathbf{k g})\end{array}$ & $\begin{array}{c}\text { Torque } \\
(\mathbf{k g - m})\end{array}$ & $\begin{array}{c}\text { Speed } \\
(\mathbf{R P M})\end{array}$ & $\begin{array}{c}\text { Output power } \\
(\mathbf{H P})\end{array}$ & $\begin{array}{c}\text { Efficiency } \\
(\mathbf{\%})\end{array}$ \\
\hline $\mathbf{0 . 0}$ & 0.200 & 0.033 & 1400 & 0.033 & 5.18 \\
\hline $\mathbf{1 . 0}$ & 0.250 & 0.138 & 1280 & 0.123 & 19.84 \\
\hline $\mathbf{2 . 0}$ & 0.300 & 0.242 & 1160 & 0.242 & 30.23 \\
\hline $\mathbf{3 . 0}$ & 0.350 & 0.347 & 1050 & 0.347 & 31.08 \\
\hline $\mathbf{4 . 0}$ & 0.450 & 0.446 & 840 & 0.446 & 39.09 \\
\hline $\mathbf{5 . 0}$ & 0.650 & 0.534 & 620 & 0.534 & 32.00 \\
\hline
\end{tabular}

Table.6 Computation of rig characteristics at different loads and constant head of $10.22 \mathrm{~m}$

\begin{tabular}{|c|c|c|c|c|c|}
\hline $\begin{array}{c}\text { Load applied } \\
(\mathbf{k g})\end{array}$ & $\begin{array}{c}\text { Spring load } \\
(\mathbf{k g})\end{array}$ & $\begin{array}{c}\text { Torque } \\
(\mathbf{k g}-\mathbf{m})\end{array}$ & $\begin{array}{c}\text { Speed } \\
(\mathbf{R P M})\end{array}$ & $\begin{array}{c}\text { Output power } \\
(\mathbf{H P})\end{array}$ & $\begin{array}{c}\text { Efficiency } \\
(\mathbf{\%})\end{array}$ \\
\hline $\mathbf{0 . 0}$ & 0.200 & 0.033 & 1750 & 0.042 & 6.56 \\
\hline $\mathbf{1 . 0}$ & 0.250 & 0.138 & 1540 & 0.155 & 23.21 \\
\hline $\mathbf{2 . 0}$ & 0.300 & 0.242 & 1370 & 0.216 & 27.89 \\
\hline $\mathbf{3 . 0}$ & 0.350 & 0.347 & 1145 & 0.277 & 35.05 \\
\hline $\mathbf{4 . 0}$ & 0.400 & 0.451 & 900 & 0.266 & 37.56 \\
\hline
\end{tabular}

Table.7 Determination of unit quantities of the rig at different loads and constant head

\begin{tabular}{|c|c|c|c|c|c|c|c|c|c|}
\hline \multirow{2}{*}{$\begin{array}{c}\text { Load } \\
\text { Applied } \\
\text { (kg) }\end{array}$} & \multicolumn{3}{|c|}{$\begin{array}{c}\text { Constant Head of } \\
7.68 \mathrm{~m}\end{array}$} & \multicolumn{3}{|c|}{$\begin{array}{c}\text { Constant Head of } \\
9.09 \mathrm{~m}\end{array}$} & \multicolumn{3}{|c|}{$\begin{array}{c}\text { Constant Head of } \\
10.22 \mathrm{~m}\end{array}$} \\
\hline & $\mathrm{Q}_{\mathrm{U}^{*}}$ & $\mathrm{IP}_{\mathrm{U}} * *$ & $\mathrm{~N}_{\mathrm{U}} * * *$ & $\mathrm{QU}^{*}$ & $\mathrm{IP}_{\mathrm{U}^{* *}}$ & $\mathrm{~N}_{\mathrm{U}} * * *$ & $\mathrm{Q}_{\mathrm{U}^{*}}$ & $\mathrm{IP}_{\mathrm{U}}{ }^{* *}$ & $\mathrm{~N}_{\mathrm{U}} * * *$ \\
\hline No load & 1.732 & 0.133 & 441 & 1.592 & 0.109 & 464 & 1.501 & 0.130 & 547 \\
\hline 1.000 & 1.830 & 0.481 & 384 & 1.592 & 0.449 & 425 & 1.551 & 0.473 & 482 \\
\hline 2.000 & 2.000 & 0.820 & 314 & 1.839 & 0.731 & 385 & 1.797 & 0.659 & 428 \\
\hline 3.000 & 2.345 & 0.966 & 267 & 2.205 & 0.901 & 348 & 1.839 & 0.848 & 358 \\
\hline 4.000 & 2.345 & 0.994 & 231 & 2.156 & 1.108 & 279 & 1.645 & 0.812 & 281 \\
\hline 5.000 & 2.050 & 0.861 & 162 & 2.004 & 0.843 & 206 & - & - & - \\
\hline 6.000 & 1.871 & 0.383 & 69 & - & - & - & - & - & - \\
\hline 7.000 & 1.871 & 0.065 & 11 & - & - & - & - & - & - \\
\hline
\end{tabular}

* Unit discharge $\left(\times 10^{-3}\right), \mathrm{m}^{3} / \mathrm{sec}$ per $\mathrm{m}$ of head, ** Unit input power $\left(\times 10^{-2}\right)$, HP per $\mathrm{m}$ of head $* * *$ Unit speed, RPM per $\mathrm{m}$ of head 


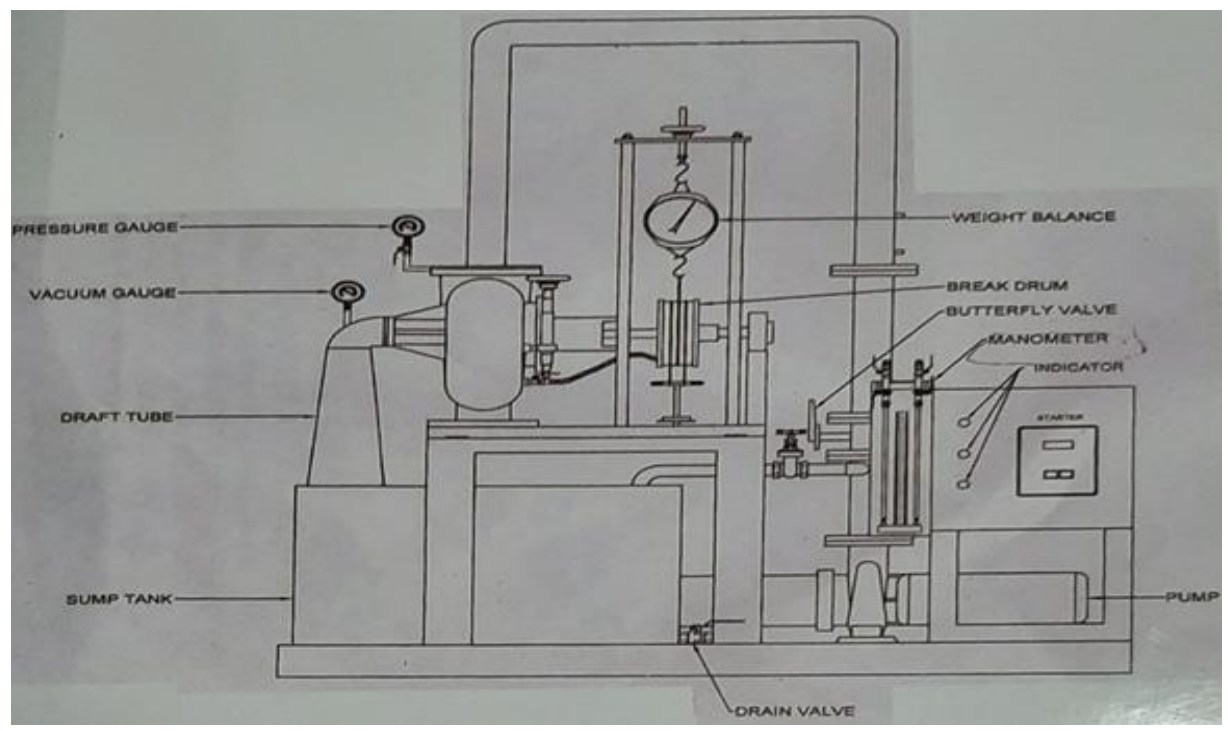

Fig.1 The schematic diagram of complete set-up of Francis turbine test rig

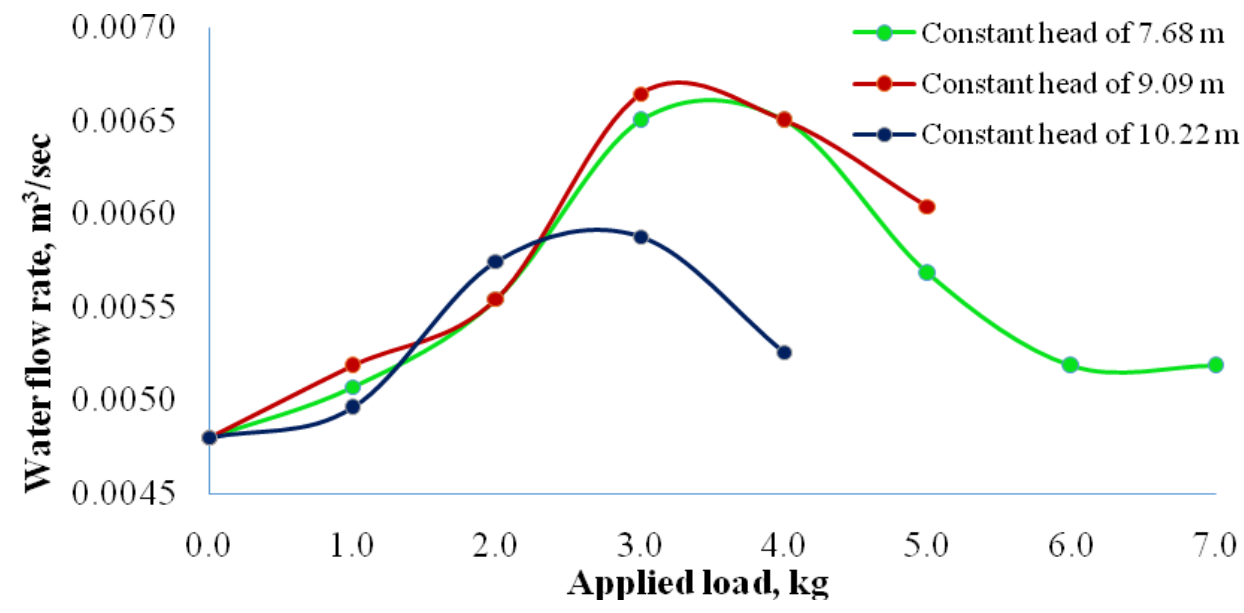

Fig.2 Water flow rate through the pipe line of the rig at different loads and heads of water

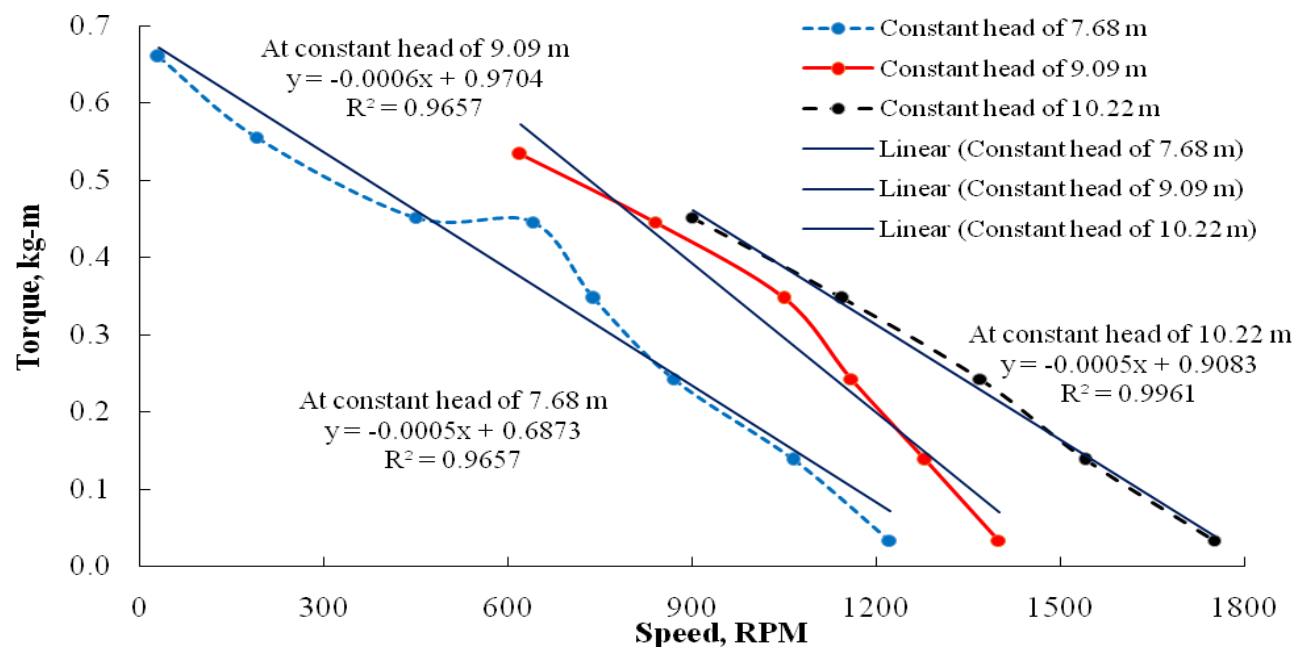

Fig.3 Variation in torque and speed of the test rigat different loads and heads of water 


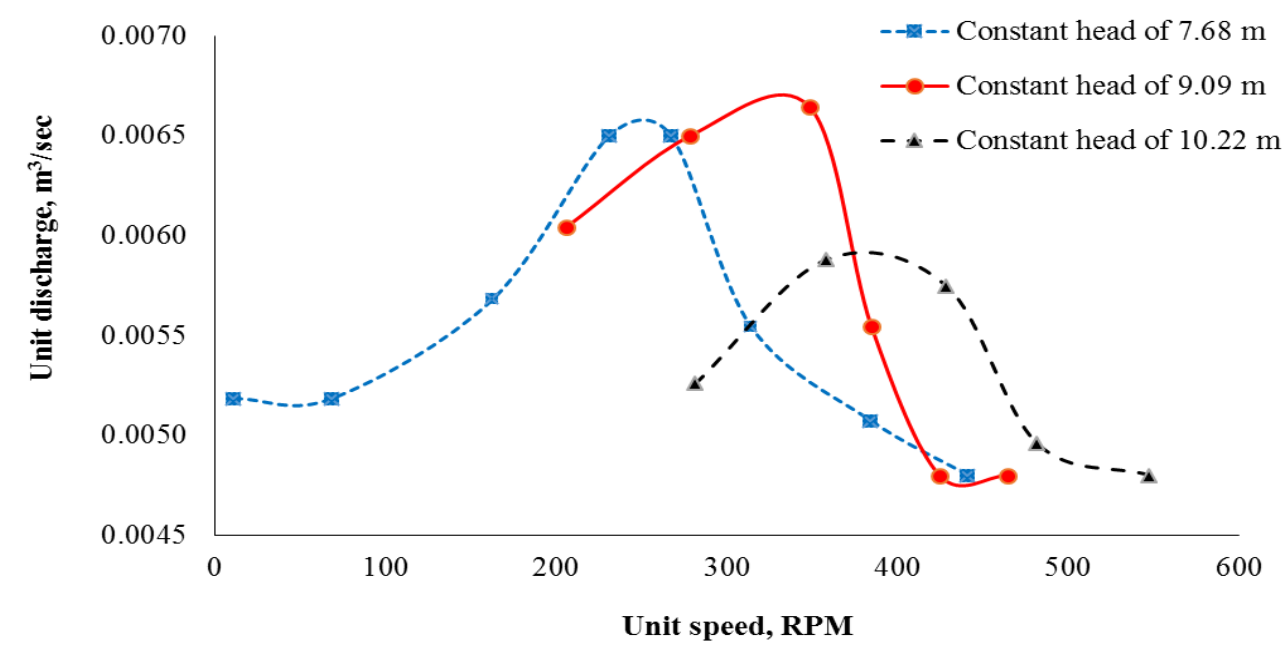

Fig.4 Variation in unit discharge and unit speed of rig at different loads and constant heads

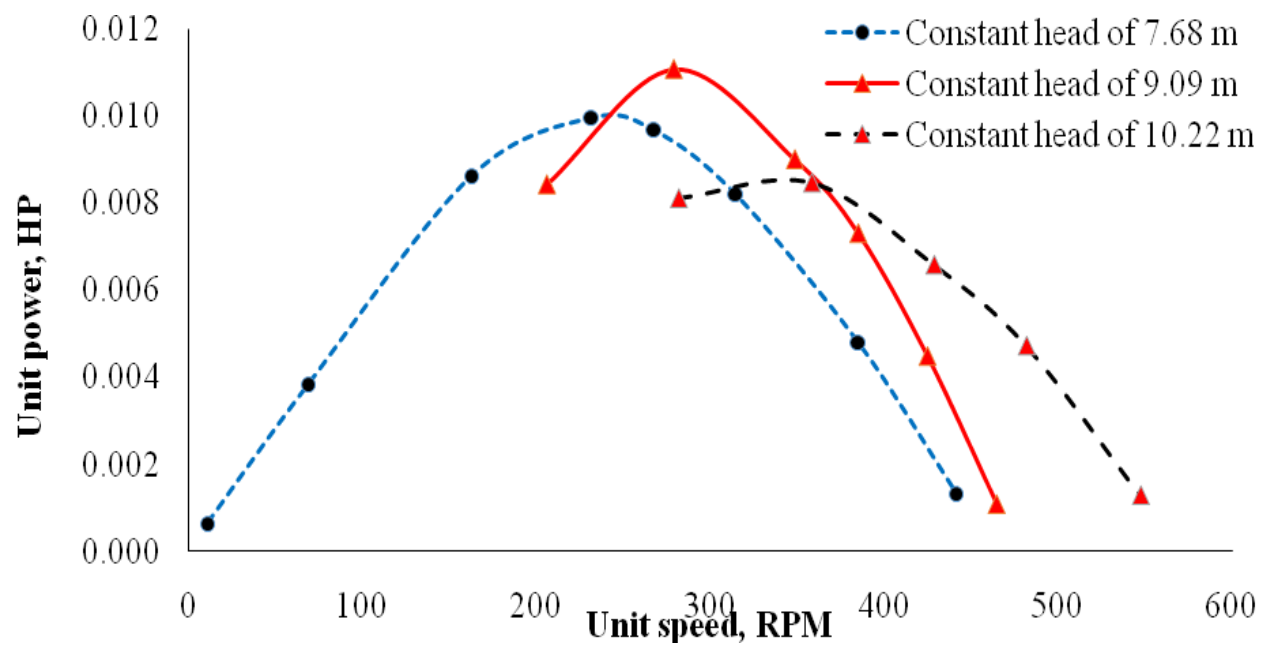

Fig.5 Variation in unit power and unit speed of the rig at different loads and constant heads

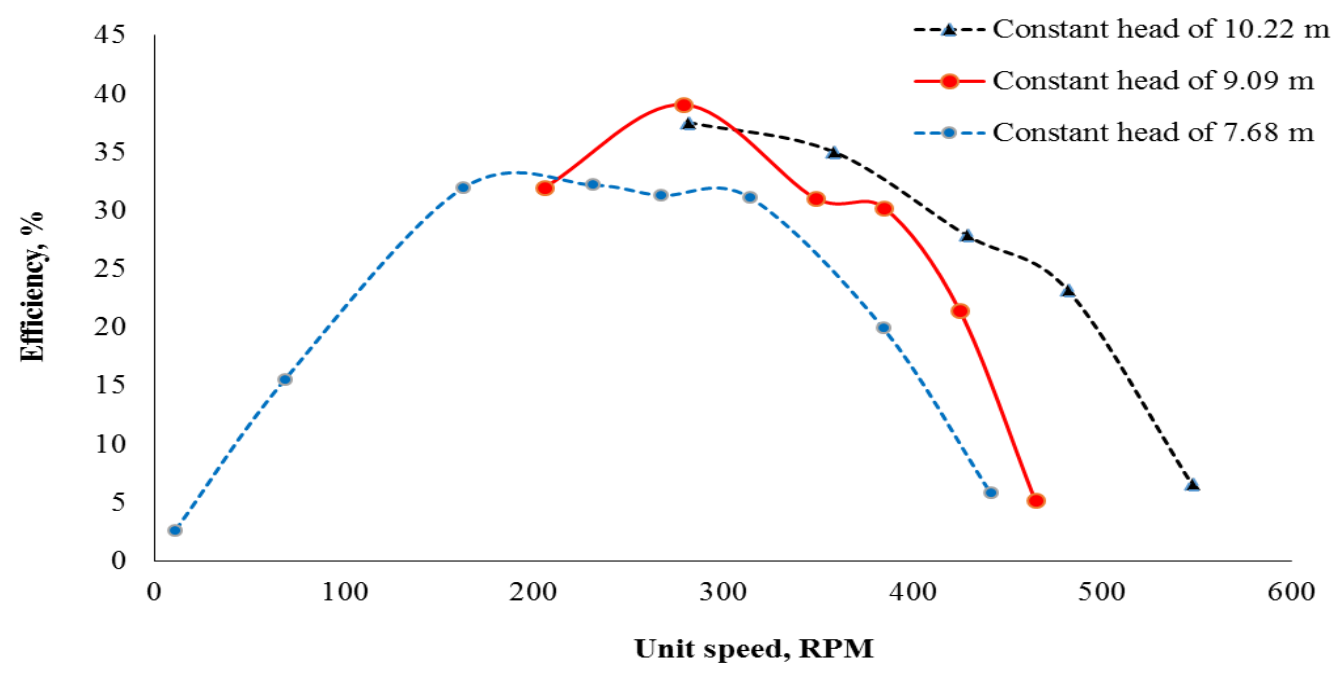

Fig.6 Variation in efficiency and unit speed of the rig at different loads and constant head 


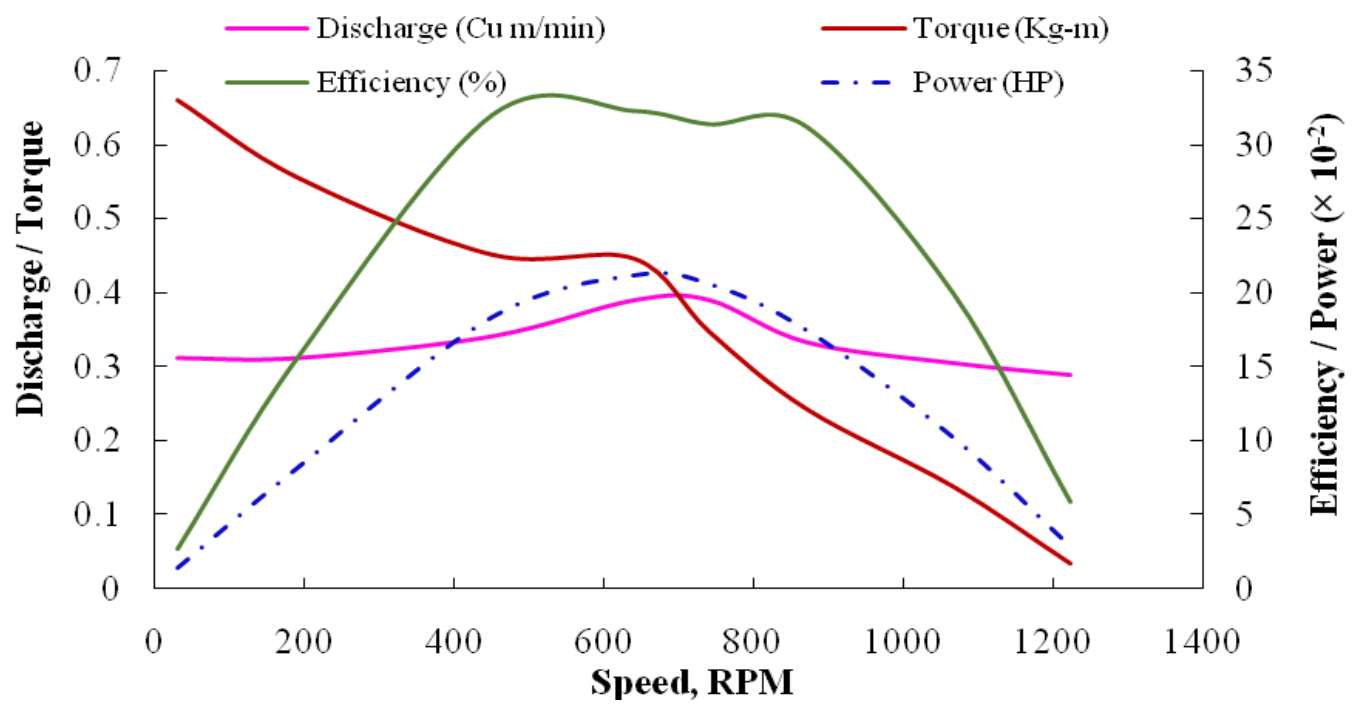

Fig.7 Characteristics curves of the test rig at different loads and constant head of $7.68 \mathrm{~m}$

The lab experiment was conducted to determine the characteristics of the Francis turbine and to study its performance at constant heads of $7.68 \mathrm{~m}, 9.09 \mathrm{~m}$ and $10.22 \mathrm{~m}$ of water. The centrifugal pump mounted on the frame of the test rig was used to develop the flow and head of water. Water flow rate through the pipe line was determined with the help a venturimeter fitted in concentric with the pipe line. The U-tube manometer filled with mercury was used to determine the pressure drop across the venturimeter. Pressure of water flow rate was measured with the help of pressure gauge and vacuum gauge fitted at inlet and outlet of the rig. The gate valve was used to control the pressure of the flowing water in order to maintain the constant head.

Loads were applied from 0 to $7.0 \mathrm{~kg}$ at constant head of $7.68 \mathrm{~m}$ to develop the torque on the runner of the turbine. Speed of the runner of the turbine was recorded for every set of observations at constant head, with the help of the Tachometer. Thus, input power, head, output power and efficiency of the test rig were determined. The unit quantities such as unit power, unit discharge and unit speed of the turbine was determined and the performance curves were prepared.
Similarly, the performance of the turbine was evaluated at various loads ranging from 0 to $5.0 \mathrm{~kg}$ at constant head of $9.09 \mathrm{~m}$ and from 0 to $4.0 \mathrm{~kg}$ at constant head of $10.22 \mathrm{~m}$ of water, respectively.

Based on results obtained during the experiments and after thorough discussions, the present study was concluded as the loads applied increases, the water flow rate and input power of the turbine increases and reaches up to the peak and then decreases at constant heads of the turbine. Inverse relationship was observed between the torque developed due to the loads applied and the speed of the runner of the turbine operating at constant head. The excellent correlation between the torque generated and the speed were found to be $99.87 \%$ at constant head of $7.68 \mathrm{~m}$ and $9.09 \mathrm{~m}$; and $99.80 \%$ at constant head of $10.22 \mathrm{~m}$ of water.

As the load applied increases, the torque developed increases but at the same time speed of the runner of the turbine decreases. The output power developed by the turbine increases with increase in load applied and reaches up to the peak values of $0.212 \mathrm{HP}$ at load of $4.0 \mathrm{~kg}, 0.534 \mathrm{HP}$ at load of $5.0 \mathrm{~kg}$ and $0.277 \mathrm{HP}$ at load of $3.0 \mathrm{~kg}$ at constant heads 
of $7.68 \mathrm{~m}, 9.09 \mathrm{~m}$ and $10.22 \mathrm{~m}$ of water, respectively and then decreases. The efficiency of the turbine increases and reaches up to the maximum values of $32.23 \%, 39.09$ $\%$ and $37.56 \%$ at the same value of load of $4.0 \mathrm{~kg}$ and at constant heads of $7.68 \mathrm{~m}, 9.09$ $\mathrm{m}$ and $10.22 \mathrm{~m}$ of water, respectively and then decreases.

\section{Acknowledgement}

Authors thankfully acknowledged the College of Agricultural Engineering, Pusa, 848125, Dr.Rajendra Prasad Central Agricultural University, Pusa, (Bihar) India.

\section{References}

Aakti, B., Amstutz, O., Casartelli, E., Romanelli, G. and Mangani, L. (2015). On the performance of a high head Francis turbine at design and off-design conditions. Journal of Physics: Conference Series579:012010 (doi:10.1088/1742-6596/579/1/012010).

Abas, A. and Kumar, Anil (2019). Evaluation of uncertainty in flow and performance parameters in Francis turbine test rig.Flow Measurement and Instrumentation. $65: 297-308$.

Christophe, N., Jorge, A. and François, A. (2004). Identification and modeling of pressure fluctuations of a Francis turbine scale model at part load operation. Proceedings of the $22^{\text {nd }}$ IAHR Symposium on Hydraulic Machinery and Systems, Stockholm,
Sweden, $\quad 1, \quad 1-17$. (https://infoscience.epfl.ch/record/5906 $1 ? \ln =\mathrm{en})$.

Foroutan, H. and Yavuzkurt, S. (2015). Unsteady numerical simulation of flow in draft tube of a hydro-turbine operating under various conditions using a partially averaged NavierStokes model. Journal of Fluids Engineering, 137 : 1-13 (DOI: 10.1115/1.4029632).

Lewis, B.J., Cimbala, J.M. and Wouden, A.M. (2014). Major historical developments in the design of water wheels and Francis hydroturbines. $27^{\text {th }}$ IAHR Symposium on Hydraulic Machinery and Systems (IAHR 2014). (doi:10.1088/1755-1315/22/1/012020).

Mishra, M.K., Khare, N. and Agrawal, A.B. (2015). Small hydro power in India: Current status and future perspectives, Renewable and Sustainable Energy Reviews, 51 : 101115.

Shanab, B.H., Elrefaie, M.E. and El-Badawy, A.A. (2017). Francis turbine prototype testing and generation of performance curves. Journal of Al Azhar University Engineering Sector, 12 (45): 13411350.

Teressa, T., Visal, G.G., Ram, P.S. and Kumar, M.S. (2018). Experimental analysis on Francis turbine at full load to determine the performance characteristics curves. International Journal of Mechanical Engineering and Technology, 9 (2) : 663-669.

\section{How to cite this article:}

Satyam Murari and Sudarshan Prasad. 2020. Numerical Evaluation of Francis Turbine Test Rig at Different Loads. Int.J.Curr.Microbiol.App.Sci. 9(07): 1020-1036.

doi: https://doi.org/10.20546/ijcmas.2020.907.120 